\title{
REVISITING THE IMPACT OF CONSUMPTION GROWTH AND INEQUALITY ON POVERTY \\ IN INDONESIA DURING THE DECENTRALISATION PERIOD
}

\author{
Riyana Miranti*, Alan Duncan ${ }^{* *}$ and Rebecca Cassells**1 \\ *University of Canberra \\ ${ }^{* *}$ Curtin University
}

\begin{abstract}
This paper analyses the consumption growth elasticity and inequality elasticity of poverty in Indonesia with a particular focus on the decentralisation period. Using provincial panel data, the effectiveness of growth in alleviating poverty across provinces is greater during the Decentralisation period post-2002 than at any earlier point in Indonesia's development history. The growth elasticity of poverty post-2002 is estimated to be -2.46 , which means that a $10 \%$ increase in average consumption per capita would reduce the poverty rate proportionally by $24.6 \%$. However, this paper also finds that the pro-poor impact of economic growth using mean consumption per capita as a proxy of economic growth (with a reduction of around 5.7 percentage points in the headcount poverty rate) has been offset to a greater extent by rising income inequality. In combination, the stronger negative impact of rising inequality has contributed to an increase of around 1.4 to 1.9 percentage points in the headcount poverty rate.
\end{abstract}

Keywords : Economic Development; Consumption Growth; Poverty; Inequality JEL Classification : O1; O4; I30, D63

\section{INTRODUCTION}

Indonesia is one of the world's largest emerging economies (EEs) according to the Organisation for Economic Corporation and Development (OECD), where together with Argentina, Brazil, China, India, Indonesia, the Russian Federation and South Africa contributed to one-fifth of global Gross Domestic Production (OECD 2011). Indonesia is also one member of the Association of Southeast Asian Nations (ASEAN) countries which was considered as one of the eight East Asian miracles because Indonesia experienced rapid economic growth at 7\% for more during the three decades prior the 1997-1998 crisis (1967-2008).

\footnotetext{
1 *Corresponding author: riyana.miranti@canberra.edu.au. The authors would like to thank Dr Michael Forster, Dr Ana Llena-Nozal and other country delegates of the OECD for funding, assistance and feedback they provided. This paper is written based on the OECD report "Trends in Poverty and Inequality in Decentralising Indonesia". The authors would also like to thank Dr Sonny Harmadi, Dr Evi Nurvidya Arifin, Dr Asep Suryahadi and Dr Jan Priebe who are involved to provide useful comments and feedback on the project. We would like to thank the Editor of BIES and two anonymous referees for their valuable feedback. Those who gave advice bear no responsibility for any errors or deficiencies in the final version. The authors also would like to thank the research assistance of Mr Erick Hansnata and the involvement of Dr Yogi Vidyattama on this project.
} 
Indonesia has experienced several distinct development phases since governance under the New Order era ended in 1998). At the end of the 1990s, the financial crisis hit many Asian countries hard, including Indonesia, where it exploded to a socio-economic crisis. Following the crisis and the recovery period, the Decentralisation process formally commenced in 2001, and was marked with new legislation, that saw greater power granted to municipal/district governments. These laws include the application of regional autonomy through Law No 22/1999 on regional governance and Law No 25/1999 on financial governance between the central and local government, and are considered to be the foundation underpinning a huge and rapid process which is often referred to as the "Big Bang" decentralisation (Hofman and Kaiser 2002). The process had to face both slow economic recovery and unsettled political conditions. Hill (2007) argues that the Indonesian economy had only begun on the track for recovery by the beginning of 2003. The two decentralisation laws were improved upon with Laws No 32/2004 and No 33/2004 that provided more clarity in regards to roles and responsibilities, despite some problems remaining unsolved (Brodjonegoro, 2009). Clearer responsibilities and inter-linkages between Central, Provincial and District governments were set out in Law 32/2004, assisting the decentralisation process further (Holtzappel 2009).

The dramatic changes in the Indonesian political and economic environments over the past decade, and arguments that exist around both positive and negative outcomes of decentralisation processes, have highlighted the importance of examining movements in social and economic patterns particularly trends in poverty and inequality over this period. In terms of poverty reduction efforts, decentralisation although not directly targeted as a sole strategy to poverty alleviation, has been expected to improve service delivery and provide better access to the poor by a credible government who knows best about what their local people need. Poverty alleviation strategies at the local level can be embedded into a number of areas of responsibilities that are associated with poverty, such as education or health support and welfare programs. Further, Sumarto et al. (2004) argues the importance of the role of civil society in decentralisation in that it may have created an opportunity to closely monitor governance and thus, giving the opportunity for the voice of the poor to be heard, which will in turn is likely to aid more effective program targeting. 
Decentralisation is also expected to promote better economic growth and per capita income and therefore increase the potential to reduce poverty. Thornton (2006) highlights several reasons that support this argument. First, local governments are in a better position to take into account of local conditions in the provision of amenities and infrastructure. Second, competition among local governments promotes incentives for investment such as lowering investment tax rates. Third, under revenue constraints local governments have an incentive to innovate in the production and supply public goods and services for its community.

Thus the paper is the extension of Miranti (2010) which examined the impact of growth and change in inequality in 1984-2002. We have extended the data set we used in Miranti (2010) to ensure that the time series data is still consistent and comparable. While this paper does not directly attempt to quantify the impact of decentralisation on poverty and inequality, it provides a detailed examination and of what happened to poverty and inequality during this period and provides some discussions about the link between these two.

The remainder of this paper comprises of three main components. The following section discusses macroeconomic and employment indicators, followed by section 3 which contains the discussion on recent poverty and inequality trends focusing on the national and sub-national analysis. Section 4 revisits the impact of consumption growth and inequality on poverty during the decentralisation period. Section 5 concludes and discusses some recommendations.

\section{MACROECONOMIC AND EMPLOYMENT INDICATORS}

This section provides background on the macroeconomic and employment indicators across development episodes in Indonesia in order to compare the decentralisation period to the periods prior to the decentralisation. This will enable better understanding on the process of Indonesian development. Several development episodes which cover the decentralisation stages to the period prior to the Asian economic crisis (1990-1996) are presented in Table 1. Economic growth declined by $13.1 \%$ during the Crisis period and then rebounded at $4 \%$ per annum during the recovery period. The recovery period which ended in 2002 overlapped with the Early Stage of decentralisation period. The decentralisation period is divided up into two distinct periods (i) Early Stage (2001-2004) and (ii) Full 
implementation period (2005-2010).The demarcation of these periods into two distinct groups is based upon knowledge of full implementation commencing after the laws implementing major funding reforms (DAU and DAK) took effect in 2004.

\section{TABLE 1 HERE}

While GDP grew on average higher than $7 \%$ annum and $5.3 \%$ per annum for GDP per capita during 1990-1996, slower average growth rates were experienced for both the early and full implementation stages (3.0 and $4.1 \%$ per annum of GDP per capita respectively). It is noted that average annual growth during the full implementation period was higher than the early decentralisation stage. Further, another alternative measurement of income taken from the household survey, mean consumption per capita, which has been argued to reflect the population welfare better. Ravallion, (1995) argues that mean consumption per capita is the better indicator on 'life cycle' or permanent income.

Mean consumption per capita increased by an average of $2.4 \%$ per year over the period between 2002 and 2010. The growth of mean consumption per capita during this period has been less than the growth during the recovery period.

Analysis of growth across industry sectors shows that the labour intensive manufacturing sector experienced a large decline in GDP growth, decreasing from 9.9\% in the period prior to the Asian Financial Crisis to $5.7 \%$ in the early decentralisation stage, and falling further to average annual growth of $3.9 \%$ in the most recent period. The service sector also experienced a large decline during the early years of decentralisation, however has since recovered, averaging growth of $6.3 \%$ per annum. Agriculture has remained relatively stable across all periods, with a slight decline in the full implementation period.

The slower pace of industry sector growth rates across the decentralisation stages is reflected in employment statistics. Employment growth per annum in the manufacturing and service sectors was also slower during the decentralisation period than prior to the crisis (Table 2). Average annual employment growth dropped by 4.3 percentage points for manufacturing and 2.6 percentage points for the service sector between 1990-1996 and 2001 - 2010. However, employment in the service sector still grew on average by $3.3 \%$ annually and higher when focusing on the full implementation period, 
where employment growth in this sector reached $4.8 \%$ per annum. The share of employment in this sector to total employment was also higher (39\%) than prior to the crisis (34.1\%). Employment elasticity (the ratio of employment growth in the service sector per annum to the ratio of service sector GDP growth per annum) in this period was relatively high at 0.66 reflecting a growing sector. Timmer (2004) argues that after the crisis, there was a shift in occupation composition, with displaced workers moving from shrinking sectors, the manufacturing to others, especially agriculture or the informal sector - particularly the service sector. As indicated in Table 2, the agriculture sector experienced positive employment growth during the crisis period, in contrast to the manufacturing sector which contracted at $12.9 \%$.

Table 2 also shows that agriculture sector employment growth had an average positive growth of $0.5 \%$ per annum across the entire decentralisation period. This is likely to reflect the fact that this sector expanded slowly. The share of employment in the agricultural sector was also still around $42.3 \%$ during 2001-2010.

\section{TABLE 2 HERE}

There has been a structural transformation of employment from the manufacturing sector prior to the crisis to the agricultural and service sectors after the crisis. Table 2 also shows the employment elasticity of the labour intensive manufacturing sector was 0.37 during 2001-2010, lower than it was during 1990-1996, prior to the crisis (0.58 as calculated in Miranti 2007).

The full implementation period also covers the period of Global Financial Crisis in 2008/2009 where Indonesia faired relatively well from this economic shock. This may infer the impact of large increases in national spending due to the Presidential election campaign during this period, which influenced increases in domestic demand; and the fact that the Indonesian export market is relatively small in the chain of globalisation when compared to neighbouring countries such as Singapore, Thailand and Malaysia (Basri and Rahardja 2010). 


\section{RECENT POVERTY AND INEQUALITY TRENDS}

\section{Patterns and Trends in Poverty}

As indicated in most previous studies examining poverty in Indonesia including Scherer and Scherer (2011) and Miranti (2010), prior to the economic crisis in 1997, Indonesia's performance in reducing poverty rates was very impressive, although the government under previous President Soeharto adopted universal policies that aimed to benefit everyone including the poor. This strategy was aimed at maintaining sufficient growth in agricultural production, with diversification and non-farm employment strategies included (Huppi and Ravallion 1991). During this period, there was one program targeted to alleviate rural poverty, particularly outside Java, with a specific Presidential Instruction/INPRES grant directed at rural poverty alleviation through the Less Developed Village INPRES (IDT) program that operated from 1994 to 1997.

As can be seen from Figure 1, there is a substantial decline in terms of the poverty rate defined at the national level between 1976-1993. Poverty reduction in the mid-1980s was claimed to be due to labour intensive employment growth fuelled by the implementation of trade liberalisation (Temple 2003).

Focusing on the period just before the economic crisis, rapid growth of GDP per capita at $5.3 \%$ per annum during 1990-1996 has contributed into rapid poverty decline of 4.9\% annually. Thus, in 1996, Indonesia reached the lowest level of poverty (according to the official published BPS data), with a rate of $11.3 \%$, down more than a half of the rate in 1976 (40\%) (Figure 1).

\section{FIGURE 1 HERE}

However, after the crisis, the poverty rate increased reaching its highest level since 1984 , at $24.2 \%$ in 1998 (Figure 1). Poverty remained quite high at $18.4 \%$ in 2001 when the decentralisation period commenced. The previous section has discussed that economic growth from the regional accounts has been slower during the decentralisation period that it was prior to the crisis while the economic growth from the household survey has been slower during the same period than it was in the 
recovery period. When growth was lower during the decentralisation period than it was during the prior development episodes, was economic growth still good for the poor?

A decreasing trend in the poverty rate between 2001 and 2005 is clearly observed in Figure 2.

However, the national poverty rate increased in 2006, which may reflect the impact of the reduction in fuel subsidies in 2005 and the increase in the price of rice and other commodities as a result of this. The latest figure in 2010 shows that the poverty rate was at 13.3\%, as a result of a slower reduction in average poverty by rate by $3.7 \%$ per year, lower than it was during the pre-crisis period (1990-1996), where the poverty rate declined by almost $5 \%$ per year.

Figure 2 also demonstrates the gap in the poverty rates between urban and rural areas which persists over time. Poverty rates in rural areas have continuously been higher than those in urban areas, with the gap the widest in 2001 at 15 percentage points. The gap in the poverty rate between urban and rural areas has been argued to be due to the accumulating impact of the role of the manufacturing and service sectors prior to the crisis, where the emphasis of industrial development was in larger urban areas, giving greater employment opportunities that could not be afforded to those in rural areas (Suryahadi et al. 2011).

Investigating further into the subnational data, Figure 2 shows the annual change in poverty rates between 2001 and 2010 and following the national trend, there was decline in poverty rates across most of the provinces except in in in Aceh and the capital city of DKI Jakarta, which experienced a worsening in poverty during the same period. For DKI Jakarta (where the poverty rate is already very low), the rate of change in terms of poverty reduction has been diminishing over time, with the overall poverty rate actually increasing by 1.2\% per year between 2001 and 2010, while for Aceh, the poverty rate may have worsened because of social conflicts that exist within this province and the disastrous earthquake and Tsunami in December 2004, with Aceh being the hardest hit region in the area. The provinces of Banten in Java and Jambi in Sumatra, experienced the most rapid decline in poverty, with annual average decreases of more than $9 \%$ during this period. ${ }^{2}$ It is also interesting to see West and East Nusa Tenggara which started with high poverty rates have experienced a catching up phenomenon with more rapid decline in their poverty rates than the rate for Indonesia on average.

2 Further investigation is required to examine which province has contributed most to reducing poverty. 


\section{FIGURE 2 HERE}

While overall poverty rates have been decreasing during the first decade of decentralisation, a general pattern of rising consumption inequality has been observed over the same period. Figure 3 shows trends in inequality across urban and rural areas in Indonesia from 1999 to 2010, as measured by the Gini coefficient and using household consumption data as the basis for calculation. ${ }^{3}$ Overall inequality increased by 5 points from 0.33 in 2002 to 0.38 in $2010 .{ }^{4}$

\section{FIGURE 3 HERE}

Two further observations are apparent from Figure 3. Firstly, inequality is greater in urban areas with patterns closely aligned to total trends. Second, rural inequality is consistently lower than urban inequality by around 7 points across the period. Both observations are likely to reflect the large increases in urban populations in recent years (Mishra 2009). To get some sense of these movements, $53 \%$ of Indonesia's population were estimated to reside in urban areas in 2010 - this is expected to reach $65 \%$ by 2025 (Bappenas 2011).

Figure 4 further examines the annualised change in inequality for the 10 year period between 2001 and 2010, again using the Gini coefficient as an indicator. The aim is to identify those provinces that either have entrenched and persistent levels of inequality, or have seen consumption inequality increase at the provincial level over the 10 year period, whether provinces show a similar trend at the national level. Only Riau experienced the reduction in terms of inequality between 2001-2010 period. Other provinces experienced increase with two new provinces of Banten and Gorontalo show the most rapid annual increase in inequality over the decade.

FIGURE 4 HERE

\section{REVISITING THE IMPACT OF CONSUMPTION GROWTH AND INEQUALITY ON POVERTY: WHAT HAPPENED DURING THE DECENTRALISATION PERIOD}

3 Please see Scherer and Scherer (2011) in regards to some caveats of Gini coefficient as inequality measure. They have argued that Gini coefficients are considered low since SUSENAS data do not capture the expenditure of the rich very well.

4 Please see Miranti et al. (2013) on the discussion in regards to potential causes behind this increasing inequality. 
A series of aggregate measures of consumption growth, inequality and poverty for Indonesia have been discussed, and served to highlight some key changes that have occurred over time, and particularly over the last decade. Four important points can be summarised. First, mean consumption per capita increased by an average of $2.4 \%$ per year over the period between 2002 and 2010. Second, the degree of consumption inequality has risen over the same period, as indicated by an overall increase in the Gini coefficient measure from 0.329 in 2002 to 0.380 in 2010. Third, the national poverty headcount in Indonesia has declined substantially, from $18.2 \%$ in 2002 to $13.3 \%$ in 2010, or from $29.3 \%$ to $18.1 \%$ during the same period if the poverty line $\$ 1.25$ a day (PPP) is used. Fourth, most provincial data show similar trend of poverty and inequality across time.

The next discussion is to explore the direction and strength of associations between poverty, inequality and growth over the main development periods in Indonesia. Miranti (2010) examined the impact of changes in consumption growth and changes in inequality on headcount poverty during three development episodes between 1984 and 2002 which covered the First Liberalisation period (1984-1990); the Second Liberalisation period (1991-1996) and the Recovery period (1999-2002). ${ }^{5}$ Expanding Miranti's work using provincial data, this section incrementally examines the consumption growth elasticity of poverty during the fourth major decentralisation period, again taking into account changes in inequality. Has the decentralisation period been pro-poor? To what degree has the change in the degree of inequality offset the alleviating impact on poverty of growth in consumption?

One of the key elements in this next stage of analysis is to take account of the high degree of heterogeneity in circumstances that exist across provinces in Indonesia. To assess effectively the underlying impact of consumption growth and inequality on poverty within provinces, it is essential to control first for local differences in economic conditions. This is achieved through the use of econometric methods that exploit the longitudinal nature of provincial data on headcount poverty derived from successive series of the Indonesian SUSENAS micro survey.

5 The Second Liberalisation period was separated from the First Liberalisation period as this period was considered as a period of more cautious and slower liberalisation than the First period (see Miranti 2010 for more detailed discussion). 


\section{Data}

Data on provincial headcount poverty (since 1996), monthly mean consumption per capita and provincial inequality are sourced from SUSENAS data published by the BPS from 1984 to 2010. Prior to 1996, the provincial headcount poverty data are sourced from poverty series used in Miranti (2010) which allow more consistent comparison with the revised poverty rates published by the BPS since the 1996. In particular, Miranti (2010) has re-estimated BPS poverty figures from 1984 to 1993 using the 2003 BPS methodology.

The provincial level was chosen as an appropriate geographical unit through which to construct a consistent panel data source for empirical analysis. In this section, eleven waves of SUSENAS consumption data are used to assemble the provincial panel used in estimation - every three years from 1984 to 1996, 2002, 2005 and then annually from 2007 through to 2010. Both poverty figures and the Gini coefficient are calculated based on SUSENAS consumption data. A provincial series is therefore only available every third year from 1984 to 2005 using the SUSENAS Consumption Module (regular) data, and then annually from 2007 using the SUSENAS Consumption Module (panel) data. SUSENAS data were not collected in some years for several conflict provinces such as Aceh, Maluku and Papua. This creates a small number of missing observations, leading to an unbalanced panel of provincial data. A second issue relates to an expansion in the number of provinces from 26 prior to 2002 to 33 in 2003. To create a degree of consistency, these new provinces were reallocated back to the original provincial boundaries that occurred prior to 2002. Specifically, Bangka Belitung is combined with South Sumatra, Riau Island is combined with Riau, Banten is combined with West Java, Gorontalo is combined with North Sulawesi, West Sulawesi is combined with South Sulawesi, Maluku Utara is combined with Maluku and West Papua is combined with Papua. The end result is a workable dataset with 308 observations. These data cover 26 provinces in Indonesia. Mean per capita consumption (in expenditure terms) is preferred as a proxy of household income rather than per capita GDP income data from national or regional accounts. This follows previous literature in this field (see Deaton 2001; Ravallion and Chen 1997; Ravallion 2003; Adams Jr 2004 and the discussion in Miranti 2010) and is justified on the basis of four reasons, (i) the weak correlation 
observed between provincial headcount poverty and economic growth from either national or regional accounts (see our discussion earlier), (ii) to examine whether an increase in the average living standards has been translated into poverty reduction (trickle-down effect), (iii) mean consumption per capita is suggested to be more suitable in reflecting the welfare level (Ravallion, 1995) as it reflects the 'life-cycle' or permanent income (see our discussion earlier), so this is more suitable for poverty analysis and (iv) to allow a consistent time series of data that is used in Miranti $(2007,2010)$ which perform a basis for the regression used in this section.

It should be acknowledged that either mean per capita consumption or per capita GDP is not free from measurement errors and may cause either underestimation or overestimation of the estimate. For example, Bhalla (2002) has argued that using the survey mean as a growth proxy has the effect of seriously underestimating the growth elasticity of poverty in the developing countries although Adams Jr (2004) has found the opposite findings. Ravallion (2001) has also tried to correct to this problem by using the growth rate from the national accounts as an instrumental variable for the growth rate in the survey mean, but growth rate from the national accounts may not be the best instrument as this may be correlated with the error terms in the regression. Thus in this section, growth is defined as the percentage change in mean consumption per capita. However, for a comparison, we also include the results using the regional GDP per capita in the Appendix. Headcount poverty rates which is calculated as the proportion of poor people in the total population and Gini indices are chosen to represent provincial poverty and inequality (that is a statistical measure to the dispersion of income distribution), respectively. Both are simpler to understand compared to other types of poverty and inequality measures, and both data sources are officially published by the BPS (except for poverty data prior to 1996 used in this section) and calculated from the SUSENAS. To allow for comparisons over time, the mean consumption (expenditure) per capita data is expressed into 1984 IDR (Indonesian Rupiah) using provincial poverty lines as a deflator. Consumption growth and inequality act together to influence the provincial headcount poverty rate, with strong prior expectations of a negative relationship between poverty and mean consumption. Research also suggests a positive relationship between poverty and inequality (as measured through the Gini coefficient), for reasons discussed in Miranti (2010). Simple scatterplots of the (bivariate) 
association between poverty and either consumption (Figure 5) or inequality (Figure 6) for all periods or in each of Indonesia's development periods provide indicative support for these priors. They also reveal some variation in the strengths of such relationships over time.

\section{FIGURE 5 HERE}

\section{FIGURE 6 HERE}

Two caveats apply when seeking to draw conclusive inferences about the direction and strength of association between poverty, consumption growth and inequality using the simple representations in Figures 5 and Figure 6. Firstly, it is important that such effects are simultaneously controlled for when estimating growth and inequality elasticities of poverty. Not to do so will lead to a bias in the estimated effects - for example, ignoring the marginal impact of inequality on poverty will force the growth elasticity to absorb this additional influence.

Secondly, the apparent association between poverty and consumption in particular is affected to a large degree by systematic and persistent differences in poverty, consumption and inequality between Indonesian provinces. For example, Papua will inevitably record both a higher level of poverty, and lower mean consumption, than Jakarta, in whichever time period one examines. Not to control for such differences can also lead to bias in the apparent impact of growth and inequality on poverty within each province of Indonesia.

We deal collectively with these issues in a series of empirical specifications presented in the next section.

\section{Empirical Methodology}

Two general models are estimated to examine consumption growth and inequality elasticities of poverty, both of which are derived from the basic model suggested by Ravallion and Chen (1997) and both applied in Miranti (2010):

$\ln P_{i, t}=\gamma_{0}+\gamma_{1} \ln \operatorname{MEAN}_{i, t}+\gamma_{2} \ln \operatorname{GINI}_{i, t}+\sum_{p=1}^{P} \beta_{e p} d_{p}+\delta_{i}+\varepsilon_{i, t}$ 


$$
\begin{aligned}
& \ln P_{i, t}=\gamma_{0}+\gamma_{1} \ln \operatorname{MEAN}_{i, t}+\gamma_{2} \ln \operatorname{GINI}_{i, t}+\sum_{t=1}^{T} \beta_{t} d_{t}+\delta_{i}+\varepsilon_{i, t} \\
& \ln P_{i, t}=\gamma_{0}+\sum_{p=1}^{P} \gamma_{1 p} e_{p} \ln \operatorname{MEAN}_{i, t}+\sum_{p=1}^{P} \gamma_{2 p} e_{p} \ln G I N I_{i, t}+\sum_{p=1}^{P} \beta_{e p} e_{p}+\delta_{i}+\varepsilon_{i, t} \\
& \ln P_{i, t}=\gamma_{0}+\sum_{p=1}^{P} \gamma_{1 p} e_{p} \ln \operatorname{MEAN}_{i, t}+\sum_{p=1}^{P} \gamma_{2 p} e_{p} \ln \operatorname{GINI}_{i, t}+\sum_{t=1}^{T} \beta_{t} d_{t}+\delta_{i}+\varepsilon_{i, t}
\end{aligned}
$$

where

$P_{i, t}$

$\operatorname{MEAN}_{i, t}$

$\operatorname{GINI}_{i, t}$ represents headcount poverty in province $i$ at time $t(\%)$ represents mean consumption per capita (IDR/month, 1984 prices) is the Gini coefficient of province $i$ at time $t$

$\mathrm{t} \quad$ is the year index:

$\mathrm{t}=\{1984,1987,1990,1993,1996,1999,2002,2005,2007,2008,2009,2010)$

$d_{t} \quad$ are the year dummies for each Susenas year from 1984 to 2010 :

eg. $d_{1984}=1$ if $\mathrm{t}=1984,0$ otherwise

$e_{p} \quad$ represents dummies for four distinct development periods in Indonesia: the First

Liberalisation period (1984-1990); the Second Liberalisation period (1991-1996); the Recovery period (1999-2002); and the Decentralisation period (2003-2010): The first three periods are consistent with the ones used in Miranti (2010).

$$
\begin{aligned}
& e_{1}=1 \text { if } \mathrm{t}=\{1984,1987,1990\}, 0 \text { otherwise } \\
& e_{2}=1 \text { if } \mathrm{t}=\{1993,1996\}, 0 \text { otherwise } \\
& e_{3}=1 \text { if } \mathrm{t}=\{1999,2002\}, 0 \text { otherwise } \\
& e_{4}=1 \text { if } \mathrm{t}=\{2005,2007,2008,2009,2010\}, 0 \text { otherwise } \\
& \delta_{i} \\
& \varepsilon_{i, t} \\
& \text { is the province fixed effect (unobserved heterogeneity) } \\
& \text { is a white-noise error term that includes errors in the poverty measure. }
\end{aligned}
$$

In each case, the relationships between poverty, consumption growth and inequality take a logarithmic form for both dependent and independent variables in order that the coefficients on each of the core explanatory variables are presented directly as elasticities. ${ }^{6}$ Models $1 \mathrm{a}$ and 2a include

\footnotetext{
6 We acknowledge the possibility of reverse causality runs from poverty rates to growth of consumption percapita, but we conclude the likelihood is small as we use the same SUSENAS year as the source of poverty rates and growth of mean consumption per capita. Further, as in Ravallion and Datt in their series of papers, 1996, 1999, 2002; Ravallion and Chen 1997, and Meng, Gregory and Wang 2005); the causality runs only one way from mean consumption per capita to the headcount poverty index and not the other way around. The other possible source of endogeneity has already been solved by the fixed effects and the year dummies (due to the nature of panel data).
} 
distinct development episodes as time effects while Models $1 \mathrm{~b}$ and $2 \mathrm{~b}$ include year dummies as the time effects. Time fixed effects are controlled for to capture macroeconomic conditions in each development period or each SUSENAS consumption module year used.

Under this choice of specification, the coefficients attached to the variables involving lnMEAN refer to a one $\%$ change in monthly mean consumption per capita, and the coefficients on the variables involving lnGINI refers to a one \% change in inequality. The first specifications (1a and $1 \mathrm{~b})$ assume constant growth and inequality elasticities of poverty across all periods of Indonesian development, whereas the second specifications ( $2 a$ and $2 b$ ) generalisation that allows for a different elasticity to be estimated in each development period.

Fixed effects methods are used in this report to capture systematic and persistent provincial differences in poverty over development periods. Ravallion and Chen (1997) and Adams (2004) use First Differences estimation in their analyses to control for provincial heterogeneity. We prefer a twoway fixed effects approach to control simultaneously for both provincial heterogeneity, and systematic national trends in poverty over time. There are two alternative assumptions adopted in these fixed effect methods. First, the assumption that in any province, random errors are usually assumed to be serially independent - i.e. not serially correlated with each other across time periods (see Wooldridge 2003). Second, for a comparison, we modify this assumption by allowing the random errors to be correlated within provinces across years but uncorrelated between provinces (see Bertrand et al. (2004) and Hoechle (2007) for further discussion). ${ }^{7}$ For the second assumption, the clustering method is applied.

\section{Empirical Results}

Tables 3 and 4 provide a series of regression results for the range of specifications nested in equations $(1 a, 1 b)$ and $(2 a, 2 b)$ above. The first panel of results in Table 3 restrict the growth and inequality to remain constant over the full period of analysis, whereas the second panel in Table 4 provides separate elasticity estimates for each of the four main development periods in Indonesia: the First

\footnotetext{
7 We also perform the test for Cross-Sectional Dependence whether or not the residuals from a fixed effects estimation of regression model are spatially independent following Hoechle (2007) and the test has proven that the random errors are not correlated between provinces/clusters.
} 
Liberalisation period (1984-1990); the Second Liberalisation period (1991-1996); the Recovery period (1999-2002); and the Decentralisation period (2003-2010).

Both sets of results demonstrate the importance of controlling for systematic provincial differences in the estimation of consumption growth and inequality elasticities of poverty. The first two columns of results presented in Table 3 reports estimates of the (constant) growth elasticity of poverty (GEP) without controlling for provincial fixed effects. When inequality is ignored, the growth elasticity of poverty is estimated to be -1.34 (Column I). The additional control of inequality (Column II) adjusts the GEP to -1.37 (which means that a $10 \%$ increase in average consumption per capita will reduce the poverty rate proportionally by $13.7 \%)$.

The additional estimated inequality elasticity of poverty (IEP) in Column II is 0.26 , but insignificant even at the $10 \%$ level. These results are broadly in line with those of Pritchett (2010), who compares the poverty elasticity of growth as the ratio of the percentage reduction in the poverty headcount rate to the percentage increase in GDP per capita during the periods 1976-1996 and 2000-2008, but with no controls for systematic provincial differences in poverty and growth. Pritchett (2011) finds an average elasticity of -1.15 in 1976 to 1996, and a calculated GEP of -0.70 for 2000 to 2008.

When provincial fixed effects and time effects are included in estimation, two effects occur. Firstly, the estimated GEP strengthens substantially, to -2.30 when controlling only for provincial fixed effects (Column III), or -2.28 with the addition of time effects (Column IV and V). The second effect to note is the rising impact of inequality on poverty when provincial differences are accounted for. The inequality elasticity of poverty (IEP) strengthens to 0.81 and 0.86 respectively, and becomes statistically significant. This is an important result, and emphasises how the positive impact of growth on poverty across Indonesian provinces can be diluted by high levels of consumption inequality.

\section{TABLE 3 HERE}

\section{TABLE 4 HERE}

These findings are further explored in Table 4, by allowing for separate estimates of GEP and IEP across the four development periods that occurred in Indonesia from 1984 to 2010, ending with the period of decentralisation after 2002. Column V in Table 4 reports a series of growth and inequality 
elasticities of poverty for each of Indonesia's main development phases, but with no controls for systematic provincial differences. Again, results are biased downwards on this basis, but nevertheless align broadly with those of Pritchett (2011) and show a rising impact of growth on poverty as Indonesia progressed through each phase of development.

The last four columns of Table 4 provide the most reliable estimates of GEP and IEP, with respective controls for provincial fixed effects (Columns VII) and both provincial and time fixed effects (Column VIII - without the clustering method and Columns IX and X - with the clustering method applied, reproduced in Table 5 below).

Two key stories emerge from these results. Firstly, the effectiveness of growth in alleviating poverty across provinces is greater during the Decentralisation period after 2002 than at any earlier point in Indonesia's development history. The growth elasticity of poverty post-2002 is estimated to be around -2.46 , which means that a $10 \%$ increase in average consumption per capita would reduce the poverty rate proportionally by $24.6 \%$. A second important result relates to the offsetting impact of inequality on provincial poverty over time. The results from Table 4 (Column VIII) show a rising influence of inequality on provincial poverty over time, with the strength of this effect peaking during the Decentralisation period at an IEP of 1.13 (suggesting that a 10\% increase in inequality will now increase headcount poverty rates by more than $11 \%$ ). If we apply clustering methods to allow for correlation in the random errors across time within provinces (Table 4, Column IX), the inequality effects over time become less significant. The final series of estimates (Column X) further restrict the IEP to be constant over time, returning an estimated (constant) effect of 0.86 . It should be noted that the effects of other explanatory factors not separately included in the empirical specifications may be absorbed into the year and provincial fixed effects. The explanatory variables that may have not been included in the estimation include, in particular, relevant government policies or interventions such as various targeted poverty alleviation programs

\section{TABLE 5 HERE}

For comparison, the alternative measure of income growth using the RGDP per capita is also presented (see Appendix, Table A1). The results have shown that impact of growth of RGDP elasticities of poverty is smaller than the ones that utilise the consumption data. This is in line with 
the findings from Adams Jr (2004) who finds much weaker (lower) statistical relationship between growth of income measured by the national (regional) accounts and poverty reduction. This may represent the limitation of the national (regional) account data for poverty analysis as the output that is produced by a region may not necessarily be associated with the welfare of that particular region (see Appendix, Table A1, Columns A3 and A4). This result supports Miranti (2013) who has examined the determinants of regional poverty in Indonesia during 2006-2011 and finds that growth elasticity of poverty during this period using the RGDP per capita as a proxy of growth of income is estimated low at -0.28 .8$

Table A1 also shows that although the growth elasticity of poverty is negative and significant during the Decentralisation period, it is lower than the elasticities during the Second Liberalisation and the Recovery Period. It is interesting to see that none of those inequality elasticities of poverty is statistically significant.

\section{Quantifying the Consumption Growth and Inequality effects on Poverty}

Table 6 shows the quantified impacts of growth and changes in inequality effects on poverty change combining the period included in Miranti (2010) and the new Decentralisation period covering 20022010. The quantified impacts represent the contribution of growth and changes in inequality to changes in the poverty rate. It should be noted that there have been differences between the magnitudes of the results presented here and the results from Miranti (2010) which was due to the additional data and the improvement in terms of methodology, including using midpoint or average consumption or inequality during the period we investigate rather than consumption or inequality at the beginning of the period.

\section{TABLE 6 HERE}

The findings indicate an offsetting impact from inequality changes (between 1.43 to 1.88 percentage points) to the negative impact of growth of consumption on poverty change (between 5.69 to 5.71

\footnotetext{
8 Miranti (2013) has adopted slightly different specification by including other explanatory variables such as interprovincial migration, intergenerational transfers, human capital and living condition.
} 
percentage points). Although growth has been pro-poor during this Decentralisation period, the increasing degree of inequality over the same period has hampered the growth impact. In line with the national figure of consumption inequality, for most provinces other than Aceh, Maluka and Papua (for which there were no data in 2002), inequality increased noticeably during the period from 2002 to 2010. It may well be worth exploring further whether this outcome represents an adverse impact from Decentralisation for districts within a province, and if so, what mechanisms are in play that may cause such a rise in inequality.

Previous literature has conjectured that the Decentralisation in Indonesia has not improved household welfare significantly (see for example Mahi 2010) or reduced inequality (see for example Hartono and Irawan 2008). Hartono and Irawan (2008) argue that this may be because of lack of coordination between central and local governments, with local government too focused on generating local income rather than contributing to the national program of poverty alleviation.

\section{CONCLUSIONS}

This paper uses eleven waves of the National Socioeconomic Survey (SUSENAS) consumption modules to calculate the impact of consumption growth and inequality on poverty with a particular focus on the decentralisation period and taking into account unobserved heterogeneity of provinces. The results show that the growth elasticity of poverty during the decentralisation period is negative and significant. This means that an increase in average living standards in terms of consumption per capita has gone hand in hand with poverty reduction. In contrast, inequality elasticity of poverty is positive and significant, which suggests that increasing inequality is associated with an increasing poverty rate. From the findings of the unrestricted model, there were more pronounced effects of income inequality on regional poverty rates during later development periods up to decentralisation in Indonesia post-2002. The results indicate that the pro-poor impact of economic growth using mean consumption per capita as a proxy of economic growth during decentralisation (a reduction of around 5.7 percentage points in the headcount poverty rate) has been offset to a greater extent by rising income inequality (up from 0.329 in 2002 to 0.380 in 2010). In combination, the stronger 
negative impact of rising inequality has contributed to an increase of around 1.4 to 1.9 percentage points in the headcount poverty rate.

The impact of periods on poverty differs over time and it is interesting to find the quantified impact of consumption growth and inequality on poverty are the largest during the decentralisation period. In addition, the results also suggest an offsetting impact from inequality changes to the negative impact of consumption growth on poverty change. Although consumption growth has been pro-poor during the decentralisation period as in other development periods (first and second liberalisation period and the recovery period) the offsetting impacts form inequality changes may represent increased inequality in most provinces in Indonesia during 2002-2010.

The fact that increasing in inequality is countering the pro-poor growth may indicate some relevant policy implications i.e. Indonesia may need to have more specific policies to target reducing inequality and poverty rather than just relying on economic growth. These results have important implications for the design and targeting of poverty alleviation policies in Indonesia. First, the findings point to the benefits from policies designed to reduce income inequality, rather than relying solely on economic growth as a poverty alleviation strategy. Second, the goal of reducing poverty in Indonesia will be delivered more efficiently by adapting policies that address the local geographic patterns of growth and interprovincial inequality.

\section{REFERENCES}

Adams Jr, R. H. (2004) 'Economic Growth, Inequality and Poverty: Estimating the Growth Elasticity of Poverty', World Development, 32(11):1989-2014.

BAPPENAS/National Development Planning Agency (2011) ‘Masterplan: Acceleration and Expansion of Indonesia Economic Development 2011-2025, Bappenas, Jakarta.

Basri, M.C. and Rahardja, S. (2010) 'Mild Crisis, Half Hearted Fiscal Stimulus: Indonesia during the GFC', Economic Research Institute for ASEAN and East Asia (ERIA) Working Paper, ERIA, Jakarta.

Bertrand, M., Duflo, E., and Mullainathan, S. (2004) 'How much should we trust differences-indifferences estimates?'. The Quarterly Journal of Economics, 119(1): 249-275.

Bhalla, S. (2002) Imagine there's there's no country: Poverty, inequality and growth in the era of globalization, Institute for International Economics, Washington, DC.

Brodjonegoro, B. (2009) 'Fiscal decentralization and its impact on regional economic development and fiscal sustainability', in Decentralization and regional autonomy in Indonesia: Implementation and challenges, ed. C. J. G. Holtzappel, and M. Ramstedt, , ISEAS, Singapore: 196-221. 
Deaton, A. (2001) 'Counting the World's Poor: Problems and Possible Solutions', The World Bank Research Observer, 16(2):125-147.

Hartono, D. and Irawan, T. (2008) `Decentralization Policy and Equality: A Theil Analysis of Indonesian Income Inequality,' Working Papers in Economics and Development Studies (WoPEDS) 200810, Department of Economics, Padjadjaran University, Bandung.

Hill, H. (2007) 'The Indonesian Economy: Growth, Crisis and Recovery', The Singapore Economic Review, 52(2), 137-166.

Hoffman B. and Kaiser K. (2002) 'The Making of the Big Bang and its Aftermath. Can Decentralization Help Rebuild Indonesia?' Andrew Young School of Policy Studies, Georgia State University, Atlanta.

Hoechle, D. (2007) 'Robust standard errors for panel regressions with cross-sectional dependence'. Stata Journal, 7(3): 281-312.

Huppi, M. and Ravallion, M. (1991) 'The Sectoral Structure of Poverty During and Adjustment Period: Evidence for Indonesia in the Mid-1980s', World Development, 19(12): 1653-1678.

Mahi, B.R. (2010) 'Intergovernmental relations and decentralization in Indonesia: new arrangements and their impacts on local welfare', Economics and Finance Indonesia, 58(2):149-72.

Meng, X., R. Gregory and Y. Wang (2005), 'Poverty, Inequality, and Growth in Urban China, 19862000,' Journal of Comparative Economics 33(4): 710-729.

Miranti, R. (2007) 'The Determinants of Regional Poverty in Indonesia: 1984-2002', PhD Thesis, the Australian National University.

Miranti, R. (2010) 'Poverty in Indonesia 1984-2002: The Impact of Growth and Changes in Inequality', Bulletin of Indonesian Economics Studies, 46(1):79-97.

Miranti, R. (2013), Provincial Poverty Rates in Indonesia, 2006-2011, Report prepared for the TNP2K, Support for Economic Analysis Development in Indonesia (SEADI), USAID.

Miranti, R., Vidyattama, Y., Hansnata, E., Cassells, R., Duncan, A. (2013) 'Trends in Poverty and Inequality in Decentralising Indonesia', the OECD Social, Employment and Migration Working Papers No. 148, OECD Publishing.

Mishra, S.C. (2009) 'Economic Inequality in Indonesia: Trends, Causes and Policy Response', Report Commissioned by UNDCP Regional Office, Strategic Asia: Preparing for the Asian Century, UNDP, Colombo.

OECD (2011), Special Focus: Inequality in Emerging Economies (EES), From Divided We Stand: Why Inequality Keeps Rising, OECD Publishing http://www.oecd.org/els/socialpoliciesanddata/dividedwestandwhyinequalitykeepsrising.htm

Pritchett, L. (2011) ‘How Good Are Good Transitions for Growth and Poverty? Indonesia since Suharto, for Instance?, in Employment, Living Standards and Poverty in Contemporary Indonesia, C. Manning and S. Sumarto (eds.), Institute of Southeast Asian Studies, Singapore.

Ravallion, M. (1995), 'Growth and poverty: Evidence for Developing Countries in the 1980s', Economic Letters 48: 411-417. 
Ravallion, M. (2001)'Growth, Inequality and Poverty: Looking Beyond Averages,' World Development, Elsevier, 29(11): 1803-1815.

Ravallion, M. (2003) 'Measuring Pro-Poor Growth?', Economic Letters, 78 (1):93-99.Ravallion , M. and Bidani B. (1994) 'How Robust is a Poverty Profile', World Bank Economic Review, 8(1) : 75-102.

Ravallion, M. and Chen, S. (1997) 'What Can New Survey Data Tell Us About Recent Changes in Distribution and Poverty ?', World Bank Economic Review, 11(2): 357-382.

Ravallion, M and Datt, G.(1996), 'How Important to India's Poor is the Sectoral Composition of Economic Growth?', World Bank Economic Review 10(1):1-25.

Ravallion, M and Datt, G. (1999),'When is Growth Pro-Poor? Evidence from the Diverse Experience of India's States', World Bank Policy Research Paper 2263.

Ravallion, M and Datt, G. (2002), 'Why Has Economic Growth been More Pro-poor in Some States of India than Others?', Journal of Development Economics 68: 381-400.

Scherer, S. and Scherer, P. (2011) Trends in Inequality and Poverty in Indonesia since the 1990's, OECD Report.

Sumarto, S., Suryahadi, S. and Arifianto, A. (2004), 'Governance and Poverty Reduction: Evidence from Newly Decentralized Indonesia', SMERU Working Paper, Jakarta: SMERU Research Institute.

Suryahadi, A., Raya, U. R., Marbun, D., and Yumma, A. (2011) 'Accelerating Poverty and Vulnerability Reduction: Trends, Opportunities and Constraints, in Employment, Living Standards and Poverty in Contemporary Indonesia, C. Manning and S. Sumarto (eds.), Institute of Southeast Asian Studies, Singapore.

Temple, J. (2003), 'Growing into Trouble: Indonesia After 1966' in D.Rodrik (ed.), In Search of Prosperity: Analytic Narratives on Economic Growth, Princenton University Press, New Jersey.

Timmer, C. P. (2004), 'The Road to Pro-Poor Growth: the Indonesian Experience in Regional Experience', Center for Global Development Working Paper, 38.

Thornton, J. (2007), 'Fiscal decentralisation and economic growth reconsidered', Journal of Urban Economics, 61 (1): 64-70.

Wooldridge, J. M. (2003), Introductory Econometrics, 2nd, Thomson, South Western, United States.

\section{APPENDIX HERE}


TABLE 1 Economic Growth by Various Growth Episodes, 1990-2010

\begin{tabular}{|c|c|c|c|c|c|c|}
\hline & $\begin{array}{l}\text { Prior } \\
\text { to the } \\
\text { crisis } \\
(1990- \\
1996)\end{array}$ & $\begin{array}{l}\text { Crisis } \\
\text { Period } \\
(1997- \\
1998)\end{array}$ & $\begin{array}{l}\text { Recovery } \\
\text { Period } \\
(1999- \\
2002)\end{array}$ & $\begin{array}{c}\text { Early Stage } \\
\text { Decentralisation } \\
(2001-2004)\end{array}$ & $\begin{array}{c}\text { Full } \\
\text { Implementation } \\
(2005-2010)\end{array}$ & $\begin{array}{c}\text { Entire } \\
\text { Decentralisation } \\
\text { period (2001- } \\
2010)\end{array}$ \\
\hline GDP & 7.2 & -13.1 & 4.0 & 4.8 & 5.7 & 5.4 \\
\hline $\begin{array}{l}\text { GDP per capita } \\
\text { Manufacturing }\end{array}$ & 5.3 & -14.3 & 2.5 & 3.0 & 4.1 & 3.7 \\
\hline GDP & 9.9 & -11.4 & 4.2 & 5.7 & 3.9 & 4.6 \\
\hline Agriculture GDP & 3.9 & -1.3 & 1.9 & 3.4 & 3.7 & 3.5 \\
\hline Mining GDP & 5.2 & -2.8 & 3.1 & -1.6 & 2.4 & 1.1 \\
\hline $\begin{array}{l}\text { Service GDP } \\
\text { Mean } \\
\text { consumption per } \\
\text { capita }\end{array}$ & 8.8 & -3.8 & 2.5 & 4.5 & 6.3 & 5.6 \\
\hline
\end{tabular}

Note: *Data on mean consumption per capita covers 2002-2010 and due to the nature of SUSENAS consumption data which are only available for every three year up to 2005, the growth of this indicator cannot be broken down into early and full implementation period.

Source: Authors' calculations, Miranti (2010) and CEIC data 
TABLE 2 Structural Transformation of Employment

\begin{tabular}{|c|c|c|c|c|c|c|}
\hline \multirow[t]{2}{*}{$\begin{array}{l}\text { Growth } \\
\text { episodes }\end{array}$} & \multicolumn{2}{|c|}{$\begin{array}{c}\text { Agriculture, Forestry \& } \\
\text { Fisheries }\end{array}$} & \multicolumn{2}{|c|}{ Manufacturing } & \multicolumn{2}{|c|}{ Services } \\
\hline & $\begin{array}{c}\text { Employment } \\
\text { Growth } \\
\text { (\% p.a.) }\end{array}$ & $\begin{array}{c}\text { Average } \\
\text { Share of } \\
\text { Total } \\
\text { Employment } \\
\text { (\% p.a.) }\end{array}$ & $\begin{array}{l}\text { Employment } \\
\text { Growth } \\
\text { (\% p.a.) }\end{array}$ & $\begin{array}{c}\text { Average } \\
\text { Share } \\
\text { of Total } \\
\text { Employment } \\
\text { (\% p.a.) }\end{array}$ & $\begin{array}{l}\text { Employment } \\
\text { Growth } \\
\text { (\%p.a.) }\end{array}$ & $\begin{array}{c}\text { Average } \\
\text { Share of } \\
\text { Total } \\
\text { Employment } \\
\text { (\% p.a.) }\end{array}$ \\
\hline $\begin{array}{l}\text { Prior to the } \\
\text { crisis } \\
(1990-1996)\end{array}$ & -1.9 & 49.6 & 5.8 & 11.6 & 5.9 & 34.1 \\
\hline $\begin{array}{l}\text { Crisis Period } \\
(1997-1998)\end{array}$ & 6.4 & 41.9 & -12.9 & 11.9 & -0.4 & 39.8 \\
\hline $\begin{array}{l}\text { Recovery } \\
\text { Period } \\
(1999-2002)\end{array}$ & 1.9 & 44.1 & 1.7 & 13.1 & -1.2 & 37.6 \\
\hline $\begin{array}{l}\text { Early Stage } \\
\text { Decentralisation } \\
(2001-2004)\end{array}$ & 0.7 & 44.4 & -2.9 & 12.6 & 2.3 & 37.2 \\
\hline $\begin{array}{l}\text { Full } \\
\text { Implementation } \\
(2005-2010)\end{array}$ & -0.2 & 40.9 & 3.5 & 12.4 & 4.8 & 40.2 \\
\hline $\begin{array}{l}\text { Entire } \\
\text { Decentralisation } \\
\text { period } \\
(2001-2010)\end{array}$ & 0.5 & 42.3 & 1.5 & 12.5 & 3.3 & 39.0 \\
\hline $\begin{array}{l}\text { Employment } \\
\text { elasticity }\end{array}$ & 0.15 & & 0.37 & & 0.66 & \\
\hline
\end{tabular}


TABLE 3 Growth elasticity regression results (constant across development periods)

\begin{tabular}{|c|c|c|c|c|c|c|c|c|c|c|c|c|c|c|c|}
\hline \multirow[t]{2}{*}{ Explanatory variable } & \multicolumn{3}{|c|}{$\mathbf{I}$} & \multicolumn{3}{|c|}{ II } & \multicolumn{3}{|c|}{ III } & \multicolumn{3}{|c|}{ IV } & \multicolumn{3}{|c|}{$\mathbf{V}$} \\
\hline & Coeff. & $\mathrm{t}$ & Sig & Coeff. & $\mathrm{t}$ & Sig & Coeff. & $\mathrm{t}$ & Sig & Coeff. & $\mathrm{t}$ & Sig & Coeff. & $\mathrm{t}$ & Sig \\
\hline \multicolumn{16}{|l|}{ Consumption and inequality } \\
\hline In(mean consumption) & -1.34 & -20.62 & $* * *$ & -1.37 & -20.24 & $* * *$ & -2.30 & -19.36 & $* * *$ & -2.28 & -19.49 & $* * *$ & -2.28 & -8.62 & $* * *$ \\
\hline $\ln (G I N I)$ & - & & & 0.26 & 1.63 & & 0.81 & 5.60 & $* * *$ & 0.86 & 6.16 & $* * *$ & 0.86 & 3.13 & $* * *$ \\
\hline \multicolumn{16}{|l|}{ Development period } \\
\hline $\begin{array}{l}\text { EPISODE1 (First liberalisation) } \\
\text { EPISODE2 (Second }\end{array}$ & & & & & & & 0.08 & 1.85 & * & - & & & - & & \\
\hline liberalisation) & & & & & & & -0.08 & -2.24 & $* *$ & - & & & - & & \\
\hline EPISODE3 (Recovery) & & & & & & & -0.14 & -3.34 & $* * *$ & - & & & - & & \\
\hline EPISODE4 (Decentralisation) & & & & & & & - & & & - & & & - & & \\
\hline Constant & 16.18 & 25.09 & $* * *$ & 15.62 & 21.46 & $* * *$ & 23.37 & 19.94 & $* * *$ & 23.05 & 19.18 & $* * *$ & 22.55 & 2.14 & $* * *$ \\
\hline Provincial fixed effects & No & & & No & & & Yes & & & Yes & & & Yes & & \\
\hline Year effects & No & & & No & & & No & & & Yes & & & Yes & & \\
\hline Clustering & No & & & No & & & No & & & No & & & Yes & & \\
\hline Sample size & 308 & & & 308 & & & 308 & & & 308 & & & 308 & & \\
\hline $\begin{array}{l}\text { Adjusted R-squared/R-quared } \\
\text { within }\end{array}$ & 0.58 & & & 0.58 & & & 0.90 & & & 0.91 & & & 0.82 & & \\
\hline
\end{tabular}


TABLE 4 Growth elasticity regression results (varying across development periods)

\begin{tabular}{|c|c|c|c|c|c|c|c|c|c|c|c|c|}
\hline \multirow[t]{2}{*}{ Explanatory variable } & \multicolumn{3}{|c|}{ VI } & \multicolumn{3}{|c|}{ VII } & \multicolumn{3}{|c|}{ VIII* } & \multicolumn{3}{|c|}{$\mathrm{IX}^{*}$} \\
\hline & Coeff. & $\mathrm{t}$ & Sig & Coeff. & $\mathrm{t}$ & Sig & Coeff. & $\mathrm{t}$ & Sig & Coeff & $\mathrm{t}$ & Sig \\
\hline \multicolumn{13}{|l|}{ Consumption and inequality } \\
\hline EPISODE $1 x \ln ($ mean cons) & -0.88 & -6.08 & $* * *$ & -2.08 & -15.42 & $* * *$ & -2.00 & -15.49 & $* * *$ & -2.00 & -5.77 & $* * *$ \\
\hline EPISODE $2 x \ln ($ mean cons) & -1.38 & -9.11 & $* * *$ & -2.31 & -17.87 & $* * *$ & -2.33 & -19.19 & $* * *$ & -2.33 & -10.10 & $* * *$ \\
\hline EPISODE $3 x \ln ($ mean cons) & -1.38 & -8.88 & $* * *$ & -2.34 & -17.51 & $* * *$ & -2.29 & -18.25 & $* * *$ & -2.29 & -8.98 & $* * *$ \\
\hline EPISODE $4 x \ln ($ mean cons) & -1.37 & -12.81 & $* * *$ & -2.50 & -19.77 & $* * *$ & -2.46 & -20.13 & $* * *$ & -2.46 & -9.45 & $* * *$ \\
\hline EPISODE1 $x \ln ($ GINI) & 0.48 & 1.54 & & 0.52 & 2.71 & $* * *$ & 0.50 & 2.82 & $* * *$ & 0.50 & 1.34 & \\
\hline EPISODE2 $x \ln ($ GINI $)$ & 0.68 & 1.37 & & 0.54 & 1.88 & * & 0.93 & 3.49 & $* * *$ & 0.93 & 3.4 & $* * *$ \\
\hline EPISODE3 $x \ln ($ GINI $)$ & 0.36 & 0.74 & & 0.75 & 2.66 & $* * *$ & 0.92 & 3.49 & $* * *$ & 0.92 & 2.87 & $* * *$ \\
\hline EPISODE4 $x \ln (G I N I)$ & 0.77 & 2.94 & $* * *$ & 1.13 & 6.57 & $* * *$ & 1.13 & 6.87 & $* * *$ & 1.13 & 2.56 & ** \\
\hline \multicolumn{13}{|l|}{ Development period } \\
\hline EPISODE1 (First liberalisation) & - & & & - & & & - & & & - & & \\
\hline EPISODE2 (Second liberalisation) & 3.95 & 1.53 & & 2.06 & 1.55 & & - & & & - & & \\
\hline EPISODE3 (Recovery) & 4.91 & 1.84 & * & 1.48 & 1.08 & & - & & & - & & \\
\hline EPISODE4 (Decentralisation) & 3.42 & 1.52 & & 1.95 & 1.65 & * & - & & & - & & \\
\hline Constant & 10.30 & 5.82 & $* * *$ & 22.40 & 15.56 & $* * *$ & 23.94 & 18.14 & $* * *$ & 23.42 & 10.03 & $* * *$ \\
\hline Provincial fixed effects & No & & & Yes & & & Yes & & & Yes & & \\
\hline Year effects & No & & & No & & & Yes & & & Yes & & \\
\hline Clustering & No & & & No & & & No & & & Yes & & \\
\hline Sample size & 308 & & & 308 & & & 308 & & & 308 & & \\
\hline $\begin{array}{l}\text { Adjusted R-squared/R-squared } \\
\text { within }\end{array}$ & 0.63 & & & 0.90 & & & 0.92 & & & 0.85 & & \\
\hline $\begin{array}{l}\text { Prob > F for different episodes: } \\
\ln (\text { mean cons })\end{array}$ & 0.03 & & & 0.00 & & & 0.00 & & & 0.09 & & \\
\hline $\ln (G I N I)$ & 0.85 & & & 0.03 & & & 0.02 & & & 0.46 & & \\
\hline
\end{tabular}

Notes: Significance at the 1,5 or $10 \%$ levels is denoted by ${ }^{* * *},{ }^{* *}$ and * respectively. Figures in parentheses are t-ratios.

For regressions that include provincial and time fixed effects, the reference province is Jakarta and 2010 is the reference period.

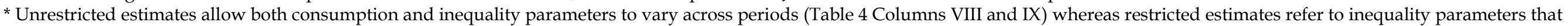
are fixed across periods between 1984 and 2002 (Table 4, Column X).

Source: $\quad$ Authors' calculations, based on SUSENAS data from 1984 to 2010. 
TABLE 4 Continued - Growth elasticity regression results (varying across development periods)

Explanatory variable

$\mathbf{X}^{*}$

Consumption and inequality

EPISODE1 $x \ln$ (mean cons)

EPISODE2 $x \ln$ (mean cons)

EPISODE3 $x \ln ($ mean cons)

EPISODE $4 x \ln ($ mean cons)

$\ln (\mathrm{GINI})$

\begin{tabular}{lll}
\multicolumn{3}{c}{$\boldsymbol{X}^{*}$} \\
Coeff. & $\mathrm{t}$ & Sig \\
\hline
\end{tabular}

$-1.99$

$-5.75 \quad * * *$

$-2.31$

$-2.27$

$-5.75 \quad * *$

$-10.58 \quad * * *$

$-2.45 \quad-9.84 \quad * * *$

$0.86 \quad 3.4 \quad * * *$

\section{Development period}

EPISODE1 (First liberalisation)

EPISODE2 (Second liberalisation)

EPISODE3 (Recovery)

EPISODE4 (Decentralisation)

Constant

Provincial fixed effects

24.29

Year effects

Clustering

Sample size

Adjusted R-squared/R-squared

within

Prob > F for different episodes:

$\ln$ (mean cons)

$*$
$*$
$*$
$*$
$*$

Notes: $\quad$ Significance at the 1,5 or $10 \%$ levels is denoted by ${ }^{* * *},{ }^{* *}$ and ${ }^{*}$ respectively. Figures in parentheses are t-ratios.

For regressions that include provincial and time fixed effects, the reference province is Jakarta and 2010 is the reference period.

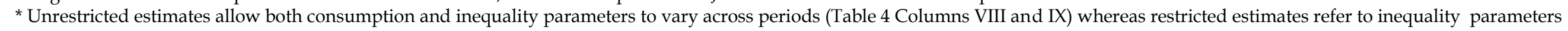
that are fixed across periods between 1984 and 2002 (Table 4, Column X).

Source: Authors' calculations, based on SUSENAS data from 1984 to 2010. 
TABLE 5 Summary of GEP and IEP, 1984-2002; 2002-2010

\begin{tabular}{lcccc}
\hline \multicolumn{1}{c}{ Period } & GEP & IEP & GEP & IEP \\
\hline First liberalisation period (1984-1990) & Unrestricted & model & \multicolumn{2}{c}{ Restricted $^{*}$} \\
Second liberalisation period (1990-1996) & -2.00 & 0.50 & -1.99 & 0.86 \\
Recovery period (1999-2002) & -2.33 & 0.93 & -2.31 & 0.86 \\
Decentralisation period (2002-2010) & -2.29 & 0.92 & -2.27 & 0.86 \\
All periods (average) & -2.46 & 1.13 & -2.45 & 0.86 \\
\hline
\end{tabular}

Source: Tables 3 and 4.

Note:* Unrestricted estimates allow both consumption and inequality parameters to vary across periods (Table 4 Columns VIII and IX) whereas restricted estimates refer to inequality parameters that are fixed across periods between 1984 and 2002 (Table 4, Column X). 
TABLE 6 Contribution of Consumption Growth and Inequality to Change in Poverty

\begin{tabular}{|c|c|c|c|}
\hline \multicolumn{4}{|l|}{ Unrestricted model ${ }^{*}$} \\
\hline \multirow[t]{2}{*}{ Period } & \multicolumn{2}{|c|}{$\begin{array}{l}\text { Contribution to poverty change } \\
\text { (percentage points ) }\end{array}$} & \multirow[t]{2}{*}{$\begin{array}{l}\text { Total poverty change } \\
\text { (percentage points) }\end{array}$} \\
\hline & Growth & Inequality Change & \\
\hline First liberalisation period (1984-1990) & -3.54 & -0.61 & -4.15 \\
\hline Second liberalisation period (1990-1996) & 0.54 & 0.79 & 1.33 \\
\hline Recovery period (1999-2002) & -4.84 & 0.99 & -3.85 \\
\hline Decentralisation period (2002-2010) & -5.71 & 1.88 & -3.83 \\
\hline All periods (average) & -13.55 & 3.05 & -10.50 \\
\hline \multicolumn{4}{|l|}{ Restricted Model ${ }^{*}$} \\
\hline \multirow[t]{2}{*}{ Period } & \multicolumn{2}{|c|}{$\begin{array}{c}\text { Contribution to poverty change } \\
\text { (percentage points) }\end{array}$} & $\begin{array}{l}\text { Total poverty change } \\
\text { (percentage points) }\end{array}$ \\
\hline & Growth & Inequality Change & \\
\hline First liberalisation period (1984-1990) & -3.53 & -1.05 & -4.58 \\
\hline Second liberalisation period (1990-1996) & 0.53 & 0.73 & 1.26 \\
\hline Recovery period (1999-2002) & -4.80 & 0.93 & -3.87 \\
\hline Decentralisation period (2002-2010) & -5.69 & 1.43 & -4.26 \\
\hline All periods (average) & -13.49 & 2.04 & -11.45 \\
\hline
\end{tabular}

Note: The contribution of growth and inequality to poverty change is calculated as the formulas

below $\left.\frac{\ln P_{t}}{\ln M E A N_{t}}=\gamma_{1} \Rightarrow \frac{\left[\frac{\Delta P_{t}}{P_{t}}\right]}{\left[\frac{\Delta M E A N_{t}}{M E A N_{t}}\right]}=\gamma_{1} \Rightarrow \Delta P_{t}=\frac{\left(\gamma_{1} * \Delta M E A N_{t} * P_{t}\right)}{M E A N_{t}}\right) \Delta \frac{\ln P_{t}}{\ln G I N I_{t}}=\gamma_{2} \Rightarrow \frac{\left[\frac{\Delta P_{t}}{P_{t}}\right]}{\left[\frac{\Delta G I N I_{t}}{G I N I_{t}}\right]}=\gamma_{2} \Rightarrow \Delta P_{t}=\frac{\left(\gamma_{2} * \Delta G I N I_{t} * P_{t}\right)}{G I N I_{t}}$

Note:* Unrestricted estimates allow both consumption and inequality parameters to vary across periods (Table 4 Columns VIII and IX) whereas restricted estimates refer to inequality parameters that are fixed across periods between 1984 and 2002 (Table 4, Column X).

Source: Authors' calculations 
Table A1. Growth elasticity regression results using RGDP per capita

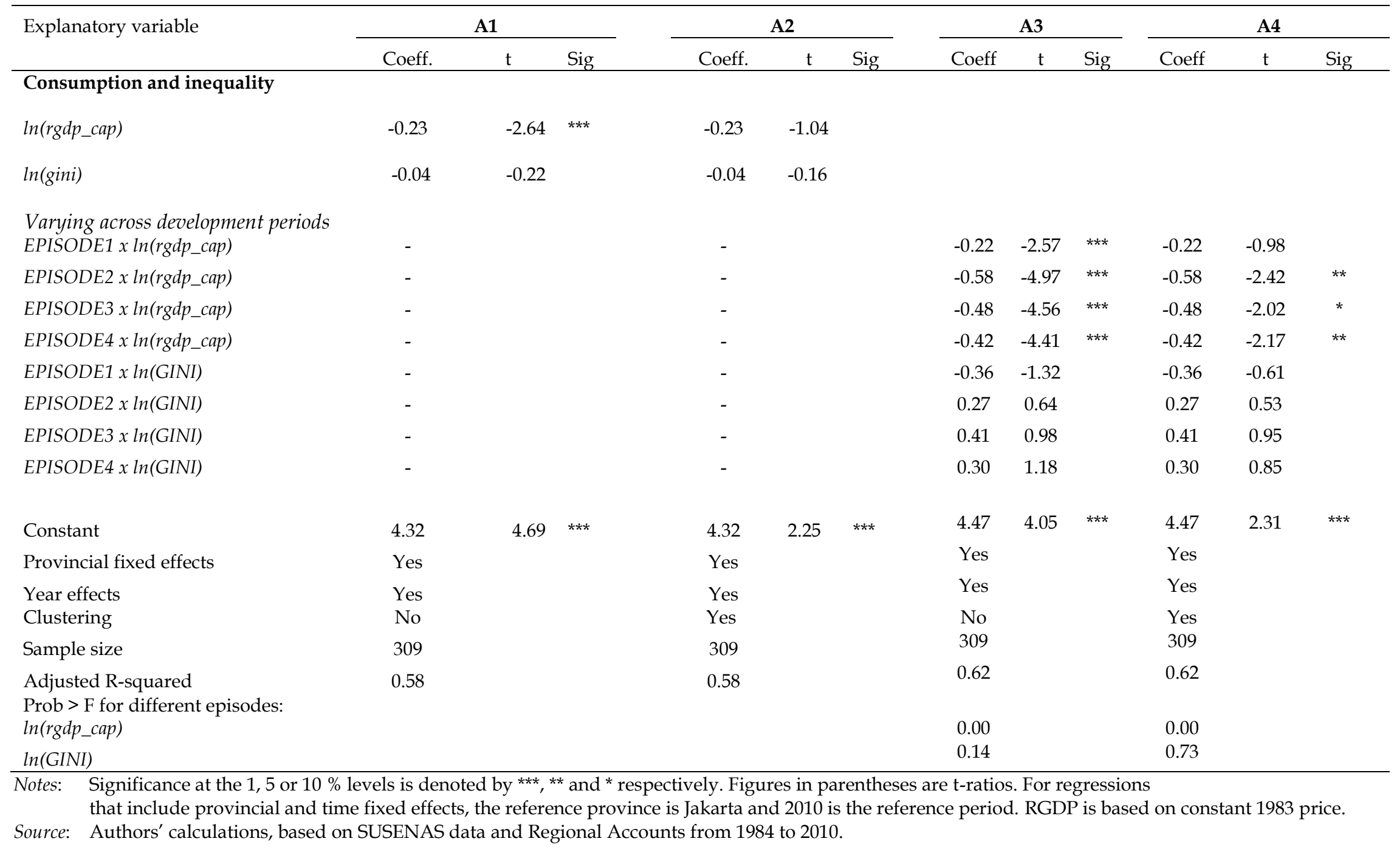


FIGURE 1 Trend in poverty rates, 1976-2010

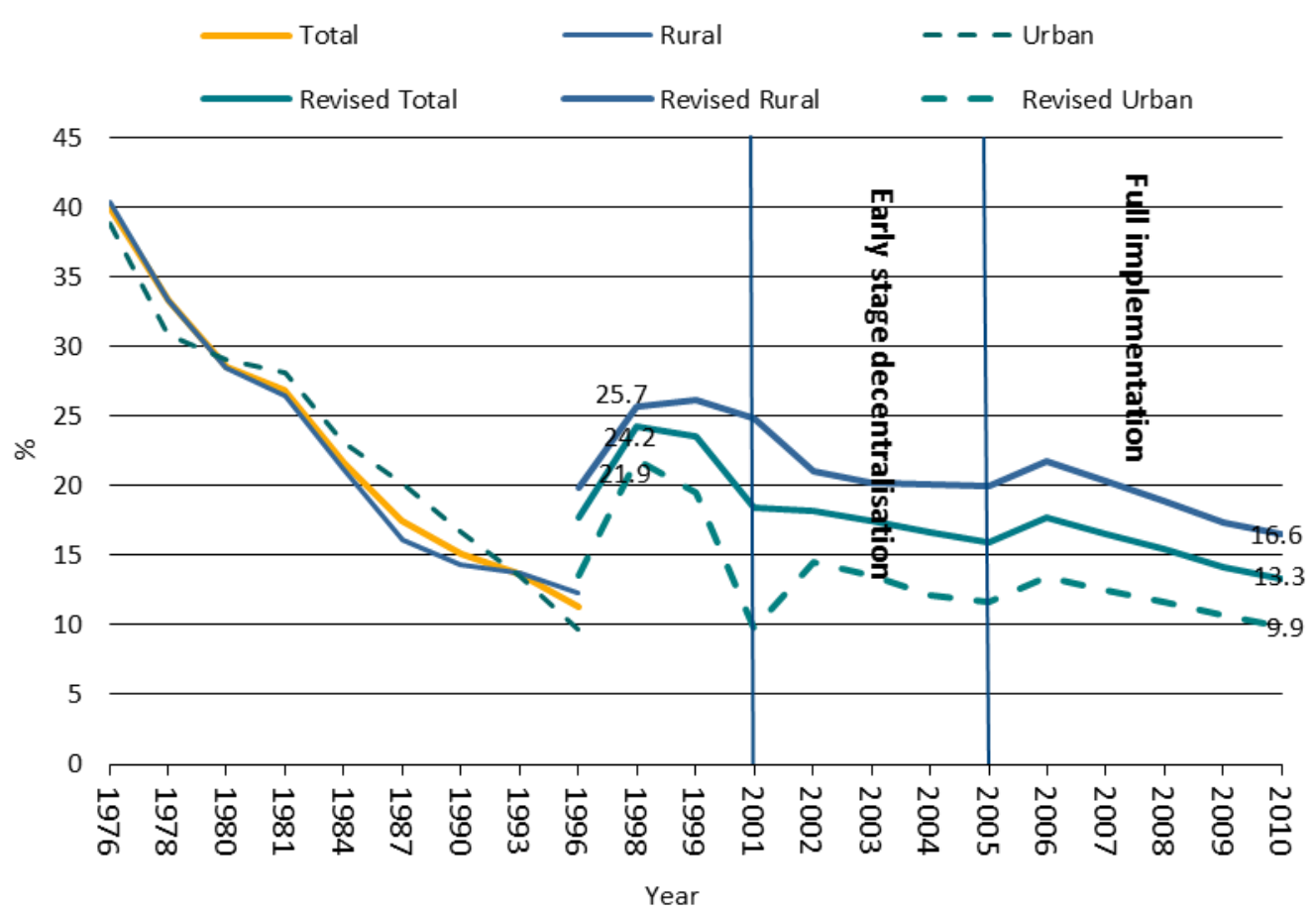

Notes: There is a break in the series from 1996 as the BPS revised its official poverty rates, due to changes in the methodology. The official poverty rates calculate the proportion of the Indonesian population who live under the poverty line, which is defined as whether a person can fulfil the cost of basic needs in terms of explicit food items covering a 2100 calorie intake per day, represented by 52 commodities and basic non-food items covering clothing, housing, education and health, represented by 51 commodities in urban and 47 commodities in rural areas.. Calorie intake is estimated through household consumption patterns. Please refer to section Measurement of Poverty for further discussion.

Source: SUSENAS, various years.

FIGURE 2 Annualised change in poverty rates, 2001-2010 (\%)

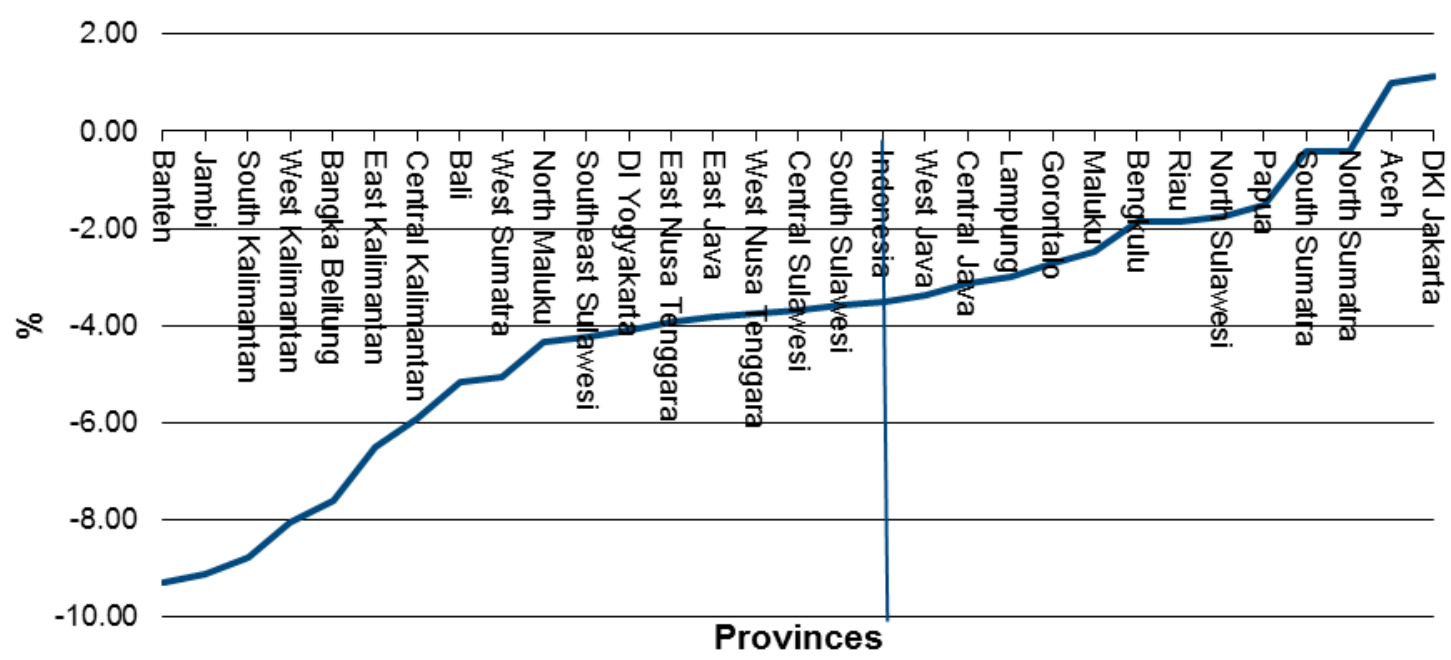

Source: Authors' calculations, SUSENAS, various years 


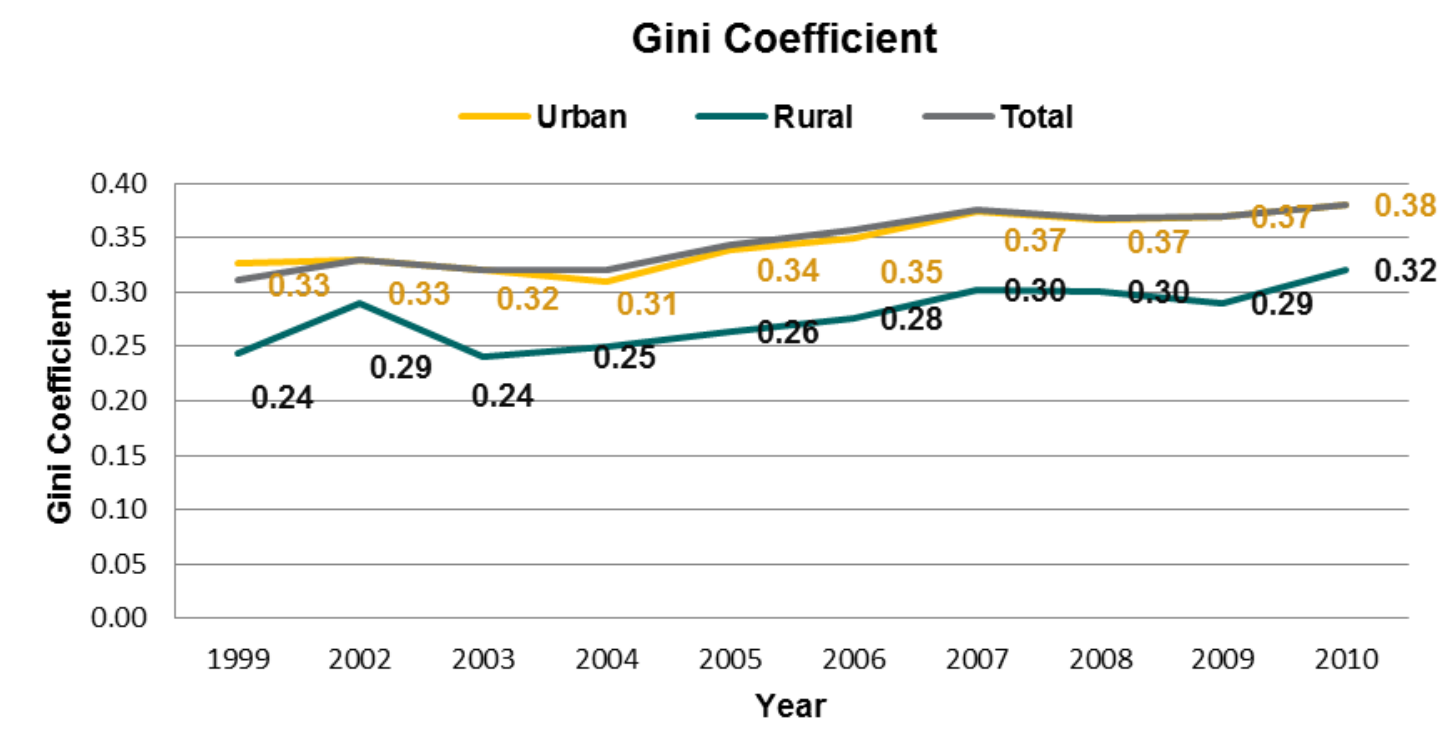

Source: SUSENAS, Statistics Indonesia, various years

FIGURE 4 Annualised Change in Gini Coefficients (2001-2010) (\%)

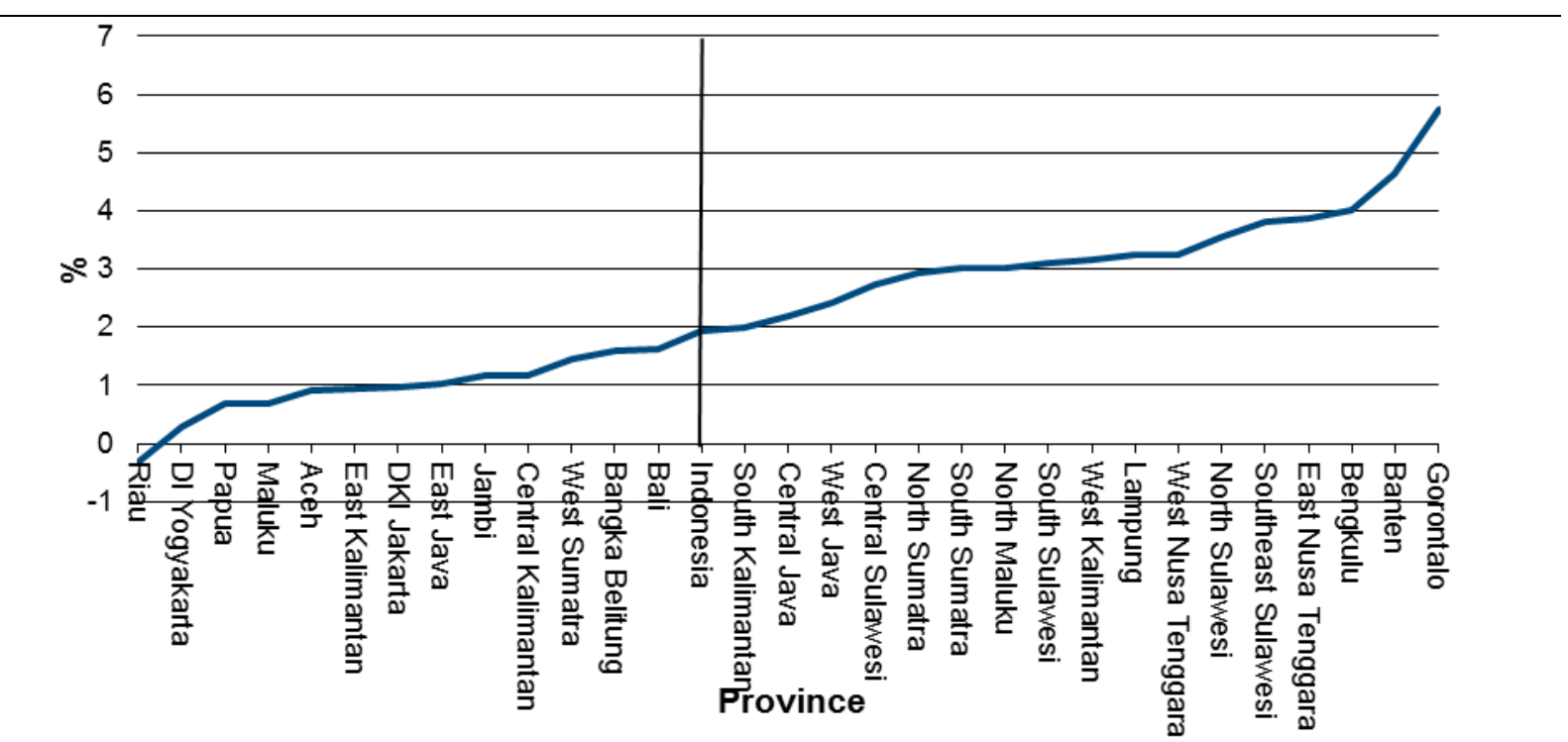

Source: Authors' calculation, SUSENAS, The Trends of Selected Socio-Economic Indicators of Indonesia, various years 
FIGURE 5 Provincial headcount poverty rates and mean per capita consumption, all period and by development period
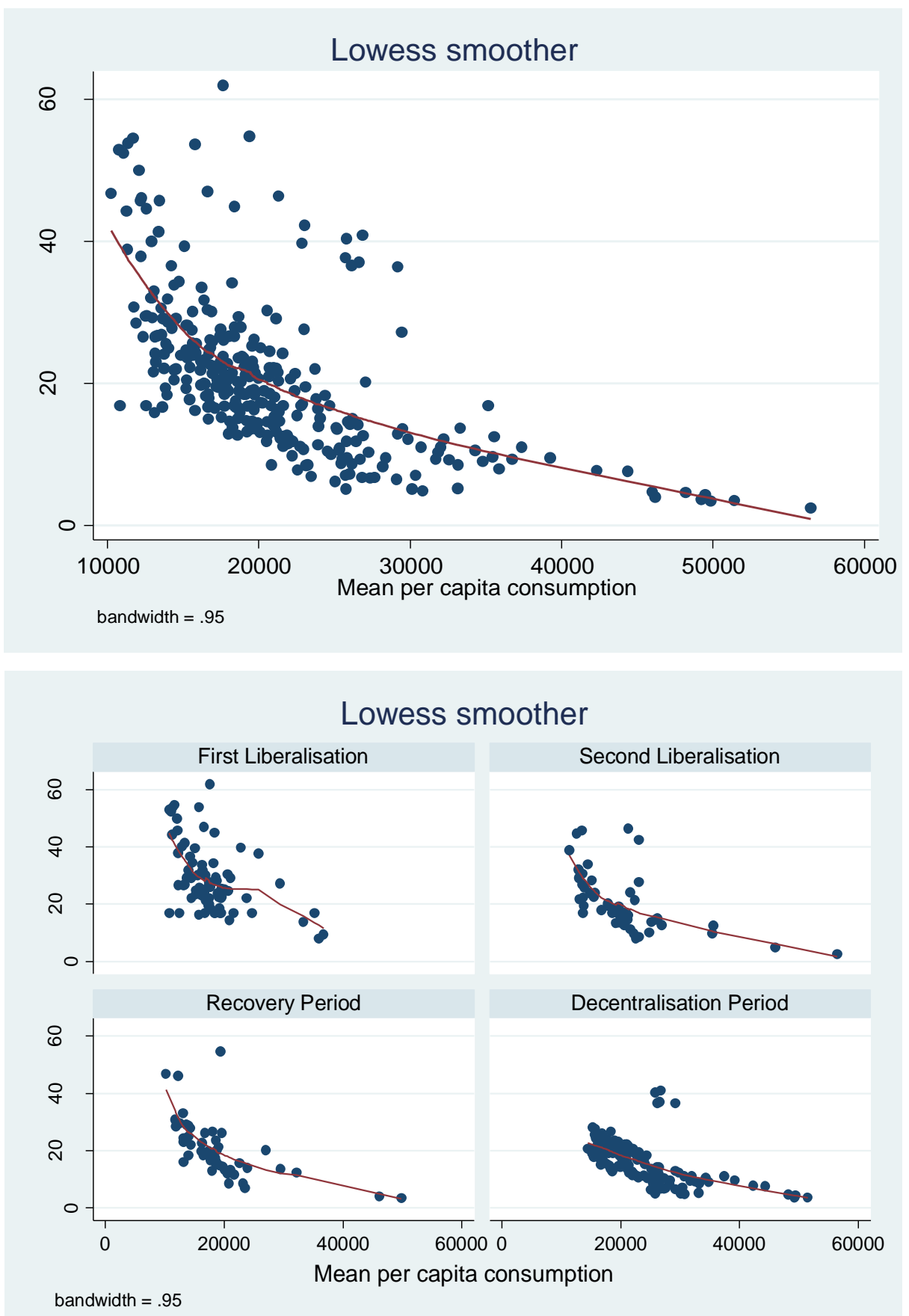

Notes:

Data on mean headcount poverty and mean Gini coefficient are calculated for each time period from 1984 to 2010 using SUSENAS data. Locally smoothed regressions are generated using the LOWESS method, with a bandwidth of 0.95 .

Source: Authors' calculations based on SUSENAS data. 

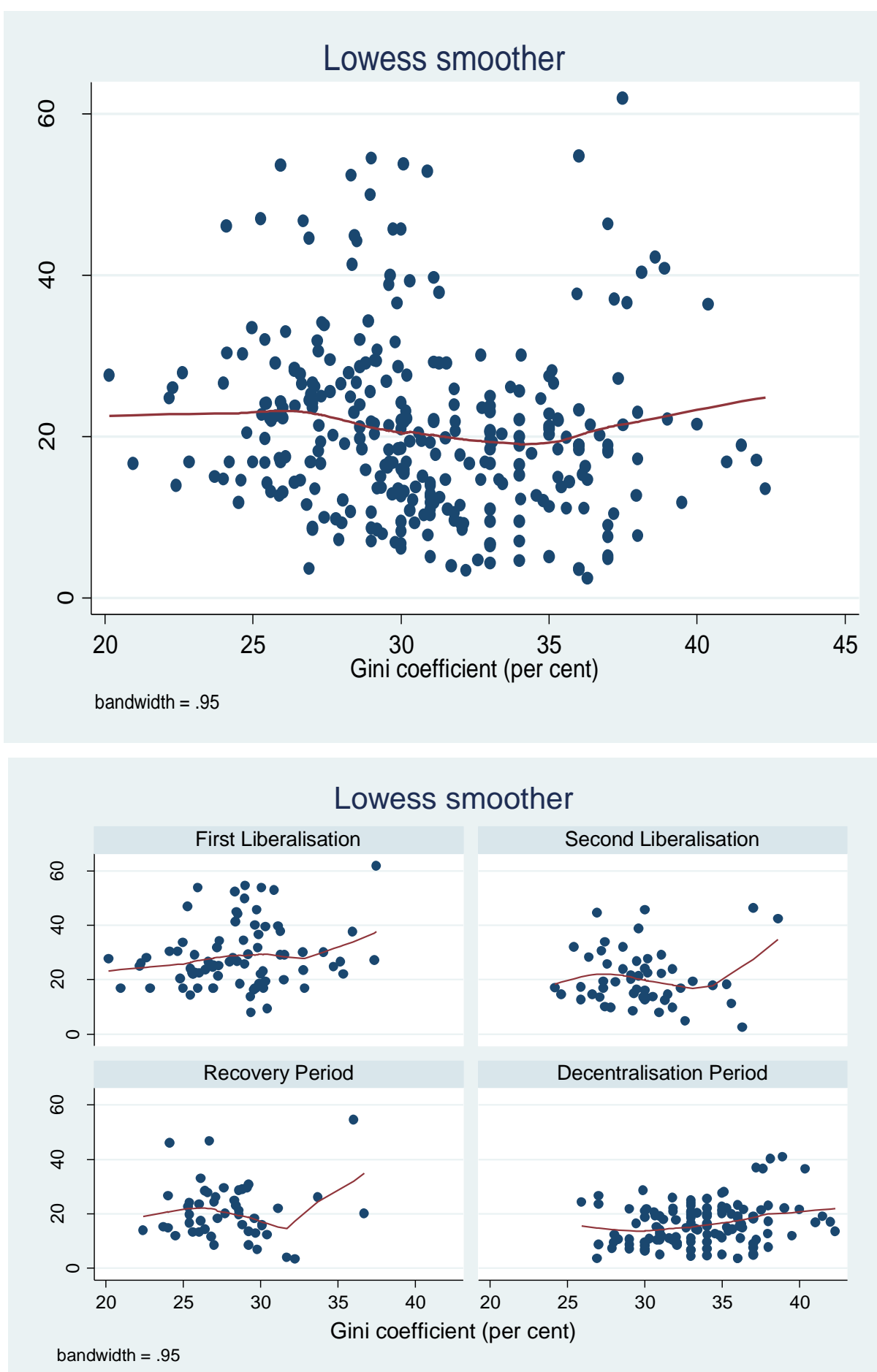

Notes:

Data on mean headcount poverty and mean Gini coefficient are calculated for each time period from 1984 to 2010 using SUSENAS data. Locally smoothed regressions are generated using the LOWESS method, with a bandwidth of 0.95 . Authors' calculations, based on SUSENAS data. 
